\title{
PERSEPSI DAN MINAT GENERASI Z DALAM BERKOPERASI GUNA MENDORONG KEBERLANJUTAN KOPERASI (STUDI PADA CU BETANG ASI)
}

\author{
Olivia Winda Ony Panjaitan, Ani Mahrita, Kanti Rahayu \\ Universitas Palangka Raya, Kalimantan Tengah, Indonesia \\ Olivia@feb.upr.ac.id
}

\begin{abstract}
ABSTRAK
Penelitian ini dilakukan untuk melihat persepsi generasi Z(Gen Z) terhadap koperasi yang diharapkan dapat menumbuhkan minat eksistensi dan mendorong sustainability (keberlanjutan) koperasi dikalangan generasi muda (Gen Z). Metode penelitian yang digunakan adalah in-depth interview dan dianalisis secara kualitatif dengan mengintrepetasi jawaban untuk memperoleh gambaran mengenai persepsi generasi muda (Gen Z) terhadap koperasi dan mengidentifikasi minat mereka dalam mengembangkan koperasi. Teknik sampling yang digunakan purposive sampling dengan jumlah responden sebanyak 10 orang. Dari hasil wawancara diketahui sebagian besar responden mempersepsikan koperasi sebagai organisasi yang ketinggalan zaman terlebih di era teknologi saat ini. Harapan wajah baru koperasi yang lebih profesional, terpercaya, modern dan berinovasi menjadi faktor pendorong minat generasi muda dalam berkoperasi.
\end{abstract}

Kata Kunci: Persepsi, minat, koperasi, generasi Z

\section{PENDAHULUAN}

Koperasi sebagai saka guru perekonomian nasional dituntut untuk mampu menyesuaikan diri dengan perkembangan zaman yang semakin menantang diera saat ini. Generasi muda khususnya generasi $\mathrm{Z}$ cenderung memandang koperasi sebagai sesuatu yang "jadul " dan kuno. Padahal sejarah membuktikan bahwa organisasi koperasi menjadi salah satu sektor penggerak kemajuan ekonomi masyarakat Indonesia.

Perkembangan koperasi memang mengalami pasang surut yang diakibatkan oleh terbatasnya kemampuan SDM dalam mengelola koperasi, ini yang menjadi alasan mengapa koperasi seolah-olah menjadi organisasi yang lambat berkembang karena tidak semua orang yang memiliki kemampuan dan pengetahuan mau 
bekerja bersama koperasi khususnya generasi muda. Citra koperasi yang "kuno" dirasa tidak menarik bagi mereka, padahal apabila dilihat dari segi kompetensi generasi muda memiliki potensi yang sangat besar untuk memajukan koperasi. Data menunjukkan bahwa di tahun 2030 indonesia akan menghadapi bonus demografi dimana jumlah penduduk usia produktif akan melebihi jumlah penduduk lansia dan anak-anak (Badan Pusat Statistik, 2012). Hal ini tentu membawa pada pertanyaan bagaimana nasib koperasi dimasa depan apakah akan bertumbuh ataukah tergerus, apabila generasi penerus tidak tergerak untuk memajukan koperasi karena pemahaman generasi muda saat ini mengenai koperasi dapat dikatogorikan cukup rendah.

CU Betang Asi merupakan salah satu koperasi simpan pinjam yang berada di wilayah Palangka Raya Kalimantan Tengah. Koperasi ini berdiri pada tanggal 23 Maret 2003 dan sampai April 2019 memiliki anggota sebanyak 39.560 orang dengan jumlah aset terbesar di Kalimantan Tengah yaitu mencapai Rp. 700 miliar lebih (CU Betang Asi, 2019; Iswanto, 2019).

Meskipun demikian, dengan aset dan anggota yang begitu besar tidak menjamin koperasi tersebut untuk bisa tetap eksis dikalangan anak muda sebagai penerus anggota koperasi kedepannya, khususnya anak muda di era generasi Z. Berdasarkan hal tersebut, maka peneliti tertarik untuk mengidentifikasi dan mengeksplor lebih lanjut bagaimana persepsi generasi $\mathrm{Z}$ memandang organisasi koperasi itu sendiri dan sejauh mana minat atau ketertarikan mereka untuk berkoperasi dalam wadah organisasi sehingga mampu menjaga sustainability (keberlanjutan) dari gerakan koperasi dimasa depan.

Mengingat beberapa penelitian sebelumnya khususnya di Kalimantan hanya meneliti tentang faktor-faktor yang memengaruhi kepuasan anggota koperasi (Lingu, 2017), serta peran dari organisasi dan anggota koperasi terhadap masyarakat dari persepsi para anggota (Carollina \& Sutarta, 2014; Arifin, Aminuyati, \& Syahrudin, 2015), namun belum ada yang meneliti bagaimana persepsi masyarakat itu sendiri khususnya generasi $\mathrm{Z}$ mengenai koperasi di era revolusi yang semakin berkembang saat ini. Persepsi mereka yang bukan anggota koperasi atau yang belum pernah bergabung dalam organisasi koperasi. 
Generasi Z sebagian besar lahir pada saat krisis ekonomi terjadi, generasi Z adalah generasi yang lahir pada tahun 1996 hingga 2010 (Fromm, 2018). Lahir dan tumbuh pada saat krisis ekonomi membuat para generasi $\mathrm{Z}$ tidak terkecuali di Indonesia menjadi berpikir lebih realistis, khususnya dalam mencari pekerjaan yang diharapkan memiliki stabilitas dan keamanan yang memadai (Dwidienawati \& Gandasari, 2018). Cara berpikir generasi $\mathrm{Z}$ terkait pekerjaan tersebut menimbulkan pertanyaan apakah mereka bersedia untuk menjadi bagian dari organisasi koperasi? Khususnya koperasi yang ada di Kalimantan Tengah yaitu CU Betang Asi. Bagaimana persepsi dan pandangan mereka terhadap organisasi koperasi? Serta sejauh mana minat mereka untuk bergabung atau menjadi bagian dari anggota koperasi? mengingat koperasi sudah mulai redup dan kurang eksis dikalangan anak muda pada saat ini.

Penelitian ini bertujuan untuk memberikan kontribusi kepada organisasi koperasi, khususnya CU Betang Asi. Hal apa saja yang dapat dilakukan oleh organisasi untuk menarik minat dan perhatian calon anggota baru, dalam hal ini adalah para generasi Z. Generasi ini sudah mulai masuk dalam dunia kerja dan diharapkan dapat menjadi penerus dan penggerak koperasi sehingga koperasi mampu bertahan, tetap eksis, dan bisa bersaing dengan instrumen keuangan lainnya ditengah era revolusi industri saat ini.

\section{KAJIAN TEORITIS}

\section{Definisi Persepsi}

Menurut Robbins (2005) persepsi merupakan suatu proses yang alami oleh seorang individu dalam mengorganisir dan mengintrepetasikan semua kesan yang ditangkap oleh indera dan akan memberikan makna atau arti bagi mereka. Sependapat dengan Robbins, definisi mengenai persepsi juga diberikan oleh Schermerhonet. al(2005) bahwa persepsi adalah proses dimana seseorang memilih, mengorganisir, mengintrepetasi, mendapat kembali dan merespon informasi yang berasal dari luar.

\section{Faktor yang mempengaruhi persepsi}

Beberapa faktor yang mempengaruhi persepsi terbagi dalam 3 (tiga) kelompok, yaitu : Faktor karakteristik pribadi yang meliputi sikap, motif, kepentingan, pengalaman dan pengharapan (ekspektasi). Faktor situasional 
meliputi waktu, keadaan sosial dan lingkungan. Faktor dalam target meliputi halhal yang baru, gerakan, bunyi, suara, ukuran, latar belakang, kedekatan dan kesamaan (Robbins, 2005).

\section{Aspek - aspek Persepsi}

Beberapa aspek - aspek persepsi menurut Walgito (2004) meliputi : Kognisi, aspek ini menyangkut komponen pengetahuan, pandangan, pengharapan, cara berpikir/mendapatkan pengetahuan dan pengalaman masa lalu, serta segala sesuatu yang diperoleh dari hasil pikiran individu pelaku persepsi. Aspek Afeksi, menyangkut komponen perasaan dan keadaan emosi individu terhadap objek tertentu serta segala sesuatu yang menyangkut evaluasi baik buruk berdasarkan faktor emosional seseorang. Aspek Konasi atau Psikomotor, menyangkut motivasi, sikap, perilaku atau aktivitas inidividu sesuai dengan persepsinya terhadap objek atau keadaan tertentu (Walgito, 2004).

\section{Indikator Persepsi}

Proses persepsi menuntut seorang individu untuk memberikan penilaian terhadap suatu objek yang dapat bersifat positif maupun negatif, senang maupun tidak senang dan sebagainya. Dengan adanya persepsi, maka akan terbentuk sikap yaitu kecenderungan yang stabil untuk berlaku atau bertindak secara tertentu didalam situasi yang tertentu pula. Menurut Walgito (2004)persepsi memiliki indikator - indikator antara lain:

\section{Penyerapan terhadap rangsang atau objek dari luar individu}

Rangsang atau objek tersebut diserap atau diterima oleh panca indera, baik penglihatan, pendengaran, peraba, pencium, dan pencecap secara sendiri-sendiri maupun bersama-sama. Dari hasil penyerapan atau penerimaan oleh panca indera tersebut akan didapat gambaran, tanggapan atau kesan didalam otak. Gambaran tersebut dapat bersifat tunggal maupun jamak, tergantung objek persepsi yang diamati. Di dalam otak terkumpul gambaran-gambaran atau kesan-kesan baik yang lama maupun yang baru saja terbentuk. Jelas tidaknya gambaran tersebut tergantung dari jelas tidaknya rangsang, normalitas alat indera dan waktu.

\section{Pengertian atau pemahaman}

Setelah terjadi gambaran-gambaran atau kesan-kesan didalam otak, maka gambaran tersebut diorganisir, digolong-golongkan (diklasifikasi) dibandingkan, 
diinterpretasi sehingga terbentuk pengertian atau pemahaman. Proses terjadinya pengertian atau pemahaman tersebut sangat unik dan cepat. Pengertian yang terbentuk tergantung juga pada gambaran-gambaran lama yang telah dimiliki individu sebelumnya.

\section{Penilaian atau evaluasi}

Setelah terbentuknya pengertian atau pemahaman, terjadilah penilaian individu. Individu membandingkan pengertian atau pemahaman yang baru diperoleh tersebut dengan kriteria atau norma yang dimiliki individu secara subjektif. Penilaian individu berbeda-beda meskipun objeknya sama. Oleh karena itu persepsi bersifat individual.

\section{Koperasi dan CU Betang Asi}

"Koperasi di Indonesia didefinisikan sebagai badan usaha dengan beranggotakan orang-seorang atau badan hukum koperasi yang melandaskan kegiatannya berdasarkan prinsip-prinsip koperasi sekaligus sebagai gerakan ekonomi rakyat berdasar atas asas kekeluargaan (Kementerian Koperasi, 2015)".

Koperasi bermula dari abad ke-20, dimulai dari usaha kecil oleh rakyat kecil. Lebih lanjut, pada tanggal 12 Juli 1947 melalui Kongres Koperasi pertama yang dilakukan di Tasikmalaya ditetapkanlah Hari Koperasi Indonesia oleh Pergerakan Koperasi (Kementerian Koperasi, 2014).

Dari segi etimologis, Credit Union (CU) berasal dari bahasa latin "credere" dan "union" atau "unus". Credere memliki arti percaya, dan union berarti perkumpulan, maka CU memiliki makna kumpulan orang yang saling percaya dalam suatu ikatan pemersatu yang sepakat untuk menabungkan uang mereka sehingga menciptakan modal bersama untuk dipinjamkan kepada anggota dengan tujuan produktif dan kesejahteraan (Irianto, 2017).

Disisi lain CU (Credit Union) juga merupakan badan usaha. Badan usaha yang tidak hanya dimiliki oleh orang-orang tertentu saja yang biasanya disebut pemegang saham atau investor, melainkan suatu badan usaha yang dimiliki oleh sekumpulan orang yang saling percaya dalam ikatan pemersatu. Yang menjadi ciri khas dari CU adalah bahwa CU mengemban 2 ( dua ) misi utama yaitu misi sosial dan misi ekonomi. Kedua misi tersebut bertujuan agar anggota menjadi berdaya dan berkemampuan untuk mandiri dan meningkatkan kualitas hidupnya dengan 
tetap memelihara solidaritas terhadap sesama anggota.

Sebagai suatu gerakan koperasi maka CU tidak lepas dari prinsip-prinsip dan nilai koperasi yang meliputi self-help (menolong diri sendiri), selfresponsibility (tanggung jawab sendiri), democracy (demokrasi), equality (persamaan), equity (keadilan) dan solidarity (solidaritas) dalam melakukan kegiatan organisasinya guna mencapai tujuan kesejahteraan bagi para anggota.

Koperasi Kredit atau Credit Union (CU) sudah masuk di Indonesia sejak tahun 1950-an, namun karna inflasi CU mengalami lumpuh total dan baru diperkenalkan pertama kali di Indonesia pada tahun 1960-an. Perjalanan CU ke Kalimantan sejak tahun 1975 dan diperkenalkan ke Kalimantan Tengah sejak tahun 1997. Ide untuk mendirikan CU di Palangkara Raya baru dimulai pada tahun 2000-an oleh Yayasan Dayak Panarung (sekarang Lembaga Dayak Panarung atau LDP). Sebelum diresmikan pada tahun 2003, CU Betang Asi yang dahulu masih menggunakan nama CU Panarung masih beranggotakan 71 orang pada tahun 2001 (CU Betang Asi, 2013).

\section{Generasi Z (Gen Z)}

Ruang lingkup dunia kerja pada era saat ini mulai diramaikan dengan generasi baru yaitu generasi Z. Generasi Z sudah mulai masuk kedalam dunia kerja sejak tahun 2016 (Dwidienawati \& Gandasari, 2018). Terdapat beberapa pendapat terkait pengelompokkan generasi Z ini. Francies dan Hoefel (2018) mengemukakan bahwa generasi Z adalah orang-orang yang lahir dari tahun 1995 hingga 2010, yaitu orang-orang yang lahir di zaman digital seperti internet, smartphone, hingga sosial media. Orang-orang yang memiliki sifat apa adanya dan bebas mengekspresikan siapa dirinya, lebih memahami perbedaaan, dan memiliki pemikiran yang realistis terkait semua hal termasuk dalam memilih pekerjaan.

Sedangkan pendapat lain, yaitu Fromm (2018) mengelompokkan generasi Z sebagai generasi yang lahir dari tahun 1996 hingga 2010. Meskipun terdapat sedikit perbedaan pada tahun awal pengelompokkan, namun pandangan terhadap generasi Z ini tetap sama yaitu generasi digital. Fromm (2018) mengemukakan bahwa generasi $\mathrm{Z}$ lahir pada era terjadi resesi hebat didunia, terjadi krisis ekonomi, dan era presiden berkulit hitam yang pertama kali. Mereka juga 
beranggapan bahwa kesuksesan tidak berasal dari keberuntungan, namun berasal dari kerja keras, karena itu generasi $\mathrm{Z}$ dianggap sebagai generasi yang realistis (Fromm, 2018)

\section{METODE}

Penelitian ini menggunakan metode kualitatif. Cooper \& Schindler (2014) dalam bukunya yang berjudul Business Research Methods menyatakan bahwa jika tujuan penelitian adalah untuk memahami suatu peristiwa secara lebih mendalam serta untuk membangun sebuah teori maka metode yang cocok adalah metode kualitatif. Metode kualitatif juga sangat ideal dilakukan jika peneliti ingin mengetahui lebih mendalam terkait perasaan, emosi, motivasi, dan persepsi seseorang.

\section{Metode Pemilihan Sampel}

Pemilihan sampel dalam penelitian ini menggunakan metode purposive sampling yaitu pemilihan sampel yang tidak dilakukan secara acak, tetapi dengan mempertimbangkan beberapa kriteria tertentu yang ditetapkan oleh peneliti dengan mempertimbangkan karakter, persepsi, dan sikap dari para responden(Cooper \& Schindler, 2014). Kriteria tersebut adalah sebagai berikut:

Tabel 1. Kriteria Responden

\begin{tabular}{|l|l|}
\hline No. & \multicolumn{1}{|c|}{ Kriteria } \\
\hline 1. & $\begin{array}{l}\text { Masyarakat atau orang yang lahir di era generasi Z yaitu dari tahun } 1996 \\
\text { hingga 2010. }\end{array}$ \\
2. & $\begin{array}{l}\text { Masyarakat atau orang yang tidak terdaftar sebagai anggota koperasi } \\
\text { apapun. }\end{array}$ \\
& $\begin{array}{l}\text { Sampel ditetapkan berjumlah 10 orang, yang terdiri dari 5 orang laki-laki } \\
\text { dan 5 orang perempuan. }\end{array}$ \\
\hline
\end{tabular}

\section{Metode Pengumpulan Data}

Pengumpulan data dalam penelitian ini menggunakan data primer yaitu wawancara langsung terhadap para informan yang selanjutnya akan disebut dengan responden. Wawancara dilakukan secara individu (individual depth interview) kepada 10 responden dengan mengajukan 8 item pertanyaan utama. Lebih lanjut, jawaban-jawaban dari para responden direkam dan dicatat untuk dianalisis dan dibuat kesimpulan penelitian. 
Proses in depth interview dilakukan terhadap responden yang termasuk dalam generasi $\mathrm{Z}$ sesuai dengan kriteria tabel 1. Lebih lanjut, responden diberi beberapa pertanyaan panduan kemudian dikembangkan sendiri oleh peneliti pada saat wawancara berlangsung. Pertanyaan-pertanyaan panduan tersebut adalah sebagai berikut:

Tabel 2. Pertanyaan-Pertanyaan Panduan

\begin{tabular}{|c|c|}
\hline No. & Item Pertanyaan \\
\hline 1. & Apakah Saudara mengetahui tentang koperasi? \\
\hline 2. & Apakah Saudara dapat menjelaskan pengertian dari koperasi? \\
\hline 3. & Apakah Saudara mengetahui CU Betang Asi? \\
\hline 4. & Koperasi jenis apakah CU Betang Asi tersebut? \\
\hline 5. & Menurut Anda apakah aman menyimpan uang di koperasi? \\
\hline 6. & $\begin{array}{l}\text { Menurut Anda apakah organisasi koperasi dapat tetap berkelanjutan } \\
\text { (susntain)? }\end{array}$ \\
\hline 7. & Apakah Anda tertarik untuk menjadi anggota koperasi? \\
\hline 8. & $\begin{array}{l}\text { Sebagai gen } \mathrm{Z} \text {, apa saran yang dapat Anda berikan atau inovasi seperti apa } \\
\text { yang dapat Anda sarankan untuk koperasi guna menarik minat calon } \\
\text { anggota, khususnya gen Z? }\end{array}$ \\
\hline
\end{tabular}

Jawaban-jawaban atas pertanyaan di atas dicatat dan direkam oleh peneliti dalam sebuah video. Selanjutnya pada akhir wawancara, peneliti melakukan konfirmasi jawaban dari para responden dengan mengulang jawaban dari para responden untuk memastikan bahwa peneliti dan responden memiliki pemahaman yang sama. Setelah sesi wawacara selesai, jawaban-jawaban tersebut kemudian disusun sesuai dengan kategori pertanyaan dan dibuat analisis pemetaan. Jawaban-jawaban yang dianggap masih kurang jelas, sebagian dikonfirmasi kembali oleh peneliti melewati wawancara lanjutan via telepon yang sebelumnya sudah mendapatkan ijin terlebih dahulu dari para responden.

\section{Metode Analisis Data}


Analisis data yang dilakukan adalah dengan menggunakan metode analisis deskriptif. Semua data kualitatif merupakan data yang berupa teks yang sesuai dengan fokus penelitian. Data teks tersebut kemudian diklasifikan atau di-koding dan diberi label atau nama sesuai dengan tema, kemudian diinterpretasi menjadi sesuatu yang bermakna atau mempunyai arti(Cooper \& Schindler, 2014). Interpretasi data teks pada setiap klasifikasi pertanyaan dapat dilihat pada tabel berikut ini:

Tabel 3. Interpretasi Data Teks

\begin{tabular}{|c|l|l|}
\hline No. & \multicolumn{1}{|c|}{ Pertanyaan } & \multicolumn{1}{|c|}{ Interpretasi Data Teks } \\
\hline 1. & $\begin{array}{l}\text { Apakah Saudara mengetahui } \\
\text { tentang koperasi? }\end{array}$ & $\begin{array}{l}\text { Kesadaran generasi Z tentang } \\
\text { keberadaan koperasi }\end{array}$ \\
\hline 2. & $\begin{array}{l}\text { Apakah Saudara dapat } \\
\text { menjelaskan pengertian dari } \\
\text { koperasi? }\end{array}$ & $\begin{array}{l}\text { Sejauh mana recognition } \\
\text { responden/kemampuan untuk } \\
\text { menjelaskan objek dalam hal ini } \\
\text { Koperasi secara holistik }\end{array}$ \\
\hline 3. & $\begin{array}{l}\text { Apakah Saudara mengetahui CU } \\
\text { Betang Asi? }\end{array}$ & $\begin{array}{l}\text { Kesadaran gen Z akan keberadaan CU } \\
\text { Betang Asi }\end{array}$ \\
\hline 4. & $\begin{array}{l}\text { Koperasi jenis apakah CU } \\
\text { Betang Asi tersebut? }\end{array}$ & $\begin{array}{l}\text { Pemahaman responden tentang CU } \\
\text { Betang ASI }\end{array}$ \\
\hline 5. & $\begin{array}{l}\text { Menurut Saudara apakah aman } \\
\text { menyimpan uang di koperasi? }\end{array}$ & $\begin{array}{l}\text { Mengetahui tingkat kepercayaan } \\
\text { generasi Z terhadap CU Betang Asi/ } \\
\text { koperasi }\end{array}$ \\
\hline 6. & $\begin{array}{l}\text { Menurut Saudara apakah } \\
\text { organisasi koperasi dapat } \\
\text { bertahan lama/ berkelanjutan? }\end{array}$ & $\begin{array}{l}\text { Mengidentifikasi persepsi responden } \\
\text { tentang peluang keberlanjutan } \\
\text { koperasi ditengah era revolusi industri } \\
\text { saat ini }\end{array}$ \\
\hline 7. & $\begin{array}{l}\text { Apakah Saudara tertarik untuk } \\
\text { menjadi anggota koperasi? }\end{array}$ & $\begin{array}{l}\text { Mengetahui tingkat ketertarikan } \\
\text { responden untuk menjadi anggota } \\
\text { koperasi }\end{array}$ \\
\hline & $\begin{array}{l}\text { Sebagai gen Z, apa saran yang } \\
\text { dapat Saudara berikan atau } \\
\text { inovasi seperti apa yang dapat } \\
\text { Saudara sarankan untuk koperasi } \\
\text { guna menarik minat calon } \\
\text { anggota, khususnya gen Z? }\end{array}$ & $\begin{array}{l}\text { Mengetahui harapan gen Z dan } \\
\text { melihat sejauh mana minat untuk } \\
\text { berkoperasi }\end{array}$ \\
\hline
\end{tabular}

\section{HASIL DAN PEMBAHASAN}

Penelitian ini bertujuan untuk mengetahui lebih dalam mengenai persepsi dan minat generasi $\mathrm{Z}$ terhadap koperasi yang melibatkan 10 (sepuluh) responden. Adapun pemetaan hasil jawaban dan pembahasan dari kedelapan item pertanyaan yang diajukan adalah sebagai berikut: 


\section{Kesadaran Generasi Z Terhadap Koperasi}

Semua responden dalam penelitian ini diberikan pertanyaan untuk mengukur tingkat kesadaran mereka tentang koperasi, dimana pertanyaanya berbunyi “Apakah Saudara mengetahui tentang koperasi?". Hasil jawaban dari pertanyaan tersebut, ada 8 (delapan) responden yang menjawab dengan tegas bahwa mereka mengetahui apa itu koperasi. Sedangkan, 2 (dua) responden lainnya menyatakan ragu-ragu dalam menjawab pertanyaan. Berdasarkan hasil penelitian, dapat disimpulkan bahwa sebagian besar responden generasi $\mathrm{Z}$ memiliki pengetahuan mengenai koperasi.

Berdasarkan hasil penelitian, dapat disimpulkan bahwa sebagian besar responden generasi $\mathrm{Z}$ memiliki pengetahuan mengenai koperasi.Pengetahuan tentang koperasi diperoleh dari penyerapan terhadap rangsangan atau objek dari luar individu yang meliputi penglihatan dan pendengaran terhadap objek (koperasi) yang berasal dari pendidikansekolah, sumberbacaan (artikel dan buku), dan pengalaman menjadi anggota koperasi. Dalam hal ini dapat disimpulkan bahwa secara umum kesadaran generasi $\mathrm{Z}$ terhadap koperasi masih sebatas teori dan konsep yang mereka peroleh dari sumber-sumber pengetahuan dari luar sehingga kurang memotivasi dan membangkitkan minat generasi ini untuk berkoperasi.

\section{Kemampuan Generasi Z Mendefinisikan Koperasi}

Untuk melihat sejauh mana generasi $\mathrm{Z}$ mampu memenjelaskan entitas koperasi, kepada setiap responden diajukan pertanyaan "Apakah Saudara dapat menjelaskan pengertian koperasi?'Berdasarkan hasil jawaban dari beberapa responden daapat ditarikk kesimpulan bahwa generasi $\mathrm{Z}$ mampu menjelaskan objek (koperasi). Adapaun jawaban dari responden sebagai berikut:

"Koperasi itu adalah suatu organisasi tempat berkumpulnya anggota-anggota dengan fokus tujuan untuk kesejahteraan anggotanya."

"Koperasi itu organisasi yang berasaskan kekeluargaan yang tujuan utamanya itu mensejahterakan anggota jadi jika anggota itu sudah sejahtera melalui koperasi tersebut artinya koperasi tersebut telah sukses seperti itu."

"Koperasi adalah suatu perkumpulan badan usaha yang ada badan hukumnya."

Apabila dilihat dari jawaban responden tersebut dapat kita simpulkan bahwa secara kognitif pengetahuan generasi $\mathrm{Z}$ cukup memadai sehingga mampu 
mendefinisikan koperasi dengan baik. Mereka mengenali koperasi sebagai suatu bentuk entitas, dengan prinsip dan asas kekeluargaan dimana semua anggotanya bersama-sama bekerjasama untuk mencapai tujuan mensejahterakan anggota.

\section{Pengenalan terhadap CU Betang ASI/koperasi}

Sebagai generasi yang tumbuh dan besar di kota palangkaraya, hampir sebagian besar responden mengenali tentang CU Betang Asi. Responden dapat memberikan gambaran dan jenis usaha (koperasi kredit) yang dilakukan oleh CU Betang Asi hal ini terlihat dari jawaban responden sebagai berikut:

"Mungkin CU Betang ASI sama aja seperti koperasi, mereka memberikan pinjaman, kita membuka tabungan, disitu kita seperti menyimpan uang disitu lalu kita juga bisa meminjam uang dengan jaminan, bunganya lebih sedikit dibandingkan dengan kita meminjam di bank atau tempat lainnya. CU Betang Asi menurut saya masih cukup popular, masih cukup bagus karena masih banyak orang-orang meminjam disitu seperti alternatif lainlah seperti meminjam di bank atau tempat lain ya masih bisa dipercaya"

Sebagian besar responden telah mengenal dengan baik koperasi kredit CU Betang Asi karena keberadaan koperasi ini diwilayah kota Palangka Raya maupun secara umum di kalimantan tengah cukup populer. Jumlah anggota koperasi CU Betang Asi ini 39.000 dan puluhan Tempat pelayanan koperasi yang tersebar di 13 kabupaten di wilayah Kalimantan Tengah.

\section{Kepercayaan Generasi Z terhadap CU Betang Asi/ koperasi}

Berkaitan dengan seberapa besar tingkat kepercayaan terhadap CU betang Asi sebagai lembaga koperasi yang cukup populer tergantung dari tata kelola koperasi itu sendiri apakah dikelola dengan benar karena akan berdampak pada nama baik koperasi. Hal ini berhubungan erat dengan peranan pengurus dan pengawas koperasi menjadi amat penting untuk membangun citra koperasi yang dapat dipercaya. Selain itu dari aspek kelembagaan berbadan hukumnya suatu lembaga dapat meningkatkan kepercayaan terhadap koperasi dimata generasi $\mathrm{Z}$ hal ini dapat dilihat dari jawaban responden berikut ini:

"Kalo lembaganya terjamin insyaallah aman tapi kalo misalnya koperasinya abal-abal nah itu harus kita waspadai terutama mungkin dari bagian masyarakat itu harus hati-hati karena kadang ada broadcast sms itu mengatasnamakan koperasi padahal itu adalah oknum yang memakai nama koperasi. Yang seperti beberapa tahun-tahun ini untuk menyimpan uang di koperasi itu masih aman ya karena tidak adanya berita terkait penyalahgunaan oleh pengurus koperasi (nilep dana tersebut)." 
"Tergantung, tergantung bagaimana pengurus koperasinya, jika pengurus koperasinya dapat dipercaya, ya pastinya bisa. Dan jika koperasinya itu memang koperasi yang terdaftar di Dinas Koperasi dan UMKM jangan koperasi yang tidak terdaftar, seperti itu, kalo tidak terdaftar pastinya tidak aman, gitu."

Kepercayaan yang diungkapkan oleh generasi $\mathrm{Z}$ tersebut dapat dikatakan sebagai persepsi berdasarkan aspek kognisi karena diungkapkan berdasarkan pengetahuan dan pengalaman yang merekadapatkan baik dari pengalaman keluarga ataupun orang disekitar lingkungan terdekat mereka. Seperti yang telah dikemukan oleh Walgito (2004) bahwa aspek persepsi kognisi merupakan hasil pemikiran yang diperoleh individu berdasarkan komponen pengetahuan, pandangan, pengharapan, serta cara berpikir/mendapatkan pengetahuan dan pengalaman masa lalu.

\section{Persepsi Generasi Z Mengenai Eksistensi Koperasi Di Era Revolusi Industri}

\section{0}

Koperasi memang berada dizaman yang sangat berbeda saat ini, dimana era revolusi industri berbasis internet of things membuat organisasi dituntut untuk beradaptasi dengan cepat. Berdasarkan hasil jawaban beberapa responden dapat disimpulkan bahwa generasi $\mathrm{Z}$ memandang keberadaan koperasi sebagai entitas yang memiliki kemampuan untuk berdaya saing asalkan terus-menerus berinovasi dan menyesuaikan diri dengan perkembangan zaman. Namun ada juga pandangan yang mengatakan bahwa koperasi yang bergerak di simpan pinjam dalam segi pelayanan dan kenyamanan dianggap tidak mampu mengungguli industri perbankan karena identik dengan kalangan menengah kebawah. Hal ini dapat dilihat dari jawaban responden:

"Koperasi bisa bertahan dimasa depan tergantung inovasi yang dilakukan untuk koperasi itu karena bisnis apapun koperasi kan sebenarnya termasuk bisnis ya walaupun bisnisnya termasuk non - nirlaba segala macam tapi setiap usaha apapun setiap badan usaha apapun harus ini ee.. menyesuaikan dengan perkembangan zaman kalo dia tidak bisa berinovasi pasti bubar."

"Masih bisa bertahan asal mereka berinovasi seperti yang saya bilang tadi memiliki inovasi jadi untuk bertahan mungkin 10 tahun, 30 tahun mendatang jika mereka memiliki inovasi yang bagus atau mungkin memiliki menyediakan semua fitur aplikasi mungkin koperasi lebih banyak menampung lagi anggota atau menarik minat masyarakat."

"Kalo koperasi sepertinya bisa saja karena mereka kan bisa..ada.. kayak.. simpan pinjam untuk orang kalangan bawah biasanya kan, sepertinya mereka masih bisa bertahan. Kalo.. di bank atau seperti yang lainnya kan sepertinya susah untuk meminjam uang apalagi kalo untuk kalangan bawah."' 
Persepsi dari beberapa generasi $\mathrm{Z}$ tersebut jika berdasarkan aspek-aspek yang telah dikemukakan oleh Walgito (2004) termasuk kedalam aspek persepesi kognisi dan afeksi, karena mereka memberikan persepsi terhadap keberlangsungan koperasi berdasarkan pada pandangan dan pengharapan atas hasil evaluasi yang mereka ketahui dari pengetahuan yang dimiliki.

\section{Ketertarikan generasi $\mathrm{Z}$ untuk menjadi anggota koperasi}

Apabila dilihat dari tingkat ketertarikan untuk menjadi anggota koperasi dapat dikatakan sangat rendah. Preferensi mereka apabila memiliki kebutuhan keuangan ataupun investasi lebih cenderung memilih dunia perbankan dibandingkan koperasi. Citra koperasi belum sebaik dunia perbankan yang memberi jaminan keamanan. Berikut beberapa jawaban responden.

"Kalo ingin bergabung sih ada emm.. cuman masih mencari - cari koperasi yang terpercaya."

"Tidak ada. (tidak tertarik, dan gak ada alasan)."

"Kayanya enggak deh, hehehe..."

"Saya memang ga ada keinginan di koperasi “

"Sepertinya eeee. Eee.. enggak yah, masalahnya kan kenyamanan kalau menurut saya, kalo menurut saya lebih enak menyimpan itu di bank."

Berdasarkan aspek-aspek persepsi yang dikemukakan oleh Walgito (2004), sikap yang ditunjukkan oleh generasi $\mathrm{Z}$ tersebut terkait ketertarikan mereka terhadap koperasi telah memuat semua aspek yaitu aspek kognisi, afeksi, psikomotor. Hal tersebut dikarenakan kecenderungan persepsi terhadap koperasi diberikan berdasarkan pengetahuan dan pengalaman yang dimiliki di masa lalu, kemudian di evaluasi sehingga membentuk sikap berdasarkan persepsinya untuk tidak memilih koperasi sebagai alternatif investasi dimasa akan datang.

\section{Harapan Generasi Z terhadap Koperasi / CU Betang Asi}

Generasi $\mathrm{Z}$ berharap agar koperasi dapat terus berinovasi mengikuti perkembangan zaman khususnya di era digital saat ini dengan memberikan fasilitas yang lebih canggih, berteknologi dan memudahkan akses seperti akun media sosial, transaksi via online, dan sebagainya. Selain itu generasi ini berharap agar pengelolaan koperasi menjadi lebih profesional dan terpercaya. Hal ini dapat dilihat dari jawaban responden:

"Fasilitasnya apa aja sih yang akan kita dapatkan ketika kita gabung ke koperasi misalnya kaya perbankan kan ada ATM nya, ada mobile banking nya segala macem nah koperasi itu juga bisa dibuat seperti itu ada digitalnya.. masyarakat itu lebih tertarik untuk ikut gabung situ." 
"Karena di era sekarang ini kan lebih ke teknologi sedang berkembang mungkin koperasi mengeluarkan seperti aplikasi untuk peminzaman jadi mungkin lebih mempermudah lah untuk masyarakat karena kalo kita sekarang mungkin dari bank kan mereka sudah punya seperti e - banking semacamnya mungkin koperasi juga perlu membuat yang seperti itu.. lebih bagus dan juga agar lebih memudahkan."

"Ya karena kita mengingat zaman sekarang kita tidak terlepas dari namanya gadget, habis tu sosial media adalah sarana untuk mengembangkan supaya koperasi ini tetap ada di zaman sekarang atau di peradaban sekarang adalah dengan kita memanfaatkan inovasi yang sudah ada dalam artian ketika dulu koperasi hanya terpatok dalam suatu daerah ini hanya sebatas anggota di kawasan daerah ini untuk mengembangkannya sekarang dengan adanya sosial media itu bisa kita manfaatkan, zaman millenial sekarang adalah dengan lebih terlibat aktif atau mengembangkan inovasi."

"Kalo dari saya yang pertama itu kepercayaan. Yang kedua itu eh..memberikan ee.. bukti-bukti yang membenarkan bahwa koperasi tersebut merupakan koperasi yang baik dimata masyarakat dan e... bisa juga dicari-cari seperti apa seperti apa sih histori dari sebuah koperasi."

\section{SIMPULAN DAN REKOMENDASI}

\section{Simpulan}

Pertumbuhan koperasi di Indonesia dapat dikatakan masih belum signifikan. Berbagai permasalahan yang sering terjadi dikoperasi meliputi aspek organisasi, usaha, sumber daya manusia dan kemampuan berinovasi membuat koperasi dipandang sebelah mata dan terkesan "kuno" sehingga mulai ditinggalkan. Saat ini koperasi berada di era yang semakin cepat berubah dimana mempengaruhi perilaku dan gaya hidup individu khususnya generasi muda. Teknologi yang semakin canggih menggeser pola dan gaya hidup kearah pola yang instan, real time, mudah, murah, nyaman dan aman.

Hal ini tentu menjadi tantangan tersendiri bagi koperasi.Secara khusus sustainability (keberlanjutan) koperasi simpan pinjam yang dikenal dengan CU (Credit Union) hendaknya dimengerti dalam arti keberlanjutan secara kelembagaan atau organisasi dan konsistensi CU sebagai gerakan cooperative untuk memberdayakan dan meningkatkan kualitas hidup anggotanya. Secara kelembagaan $\mathrm{CU}$ harus didukung dengan para pengurus dan pengawas yang mampu meningkatkan dan memastikan lembaga CU yang sehat, aman dan dapat dipercaya dengan menerapkan tata kelola yang baik. Selanjutnya keterbukaan terhadap berbagai perkembangan yang bersifat eksternal baik teknologi dan demografi hendaknya dipandang sebagai suatu peluang bagi koperasi untuk terus 
berbenah diri, beradaptasi dan berinovasi sehingga dapat mempertahankan eksistensinya.Peran dan sinergi dari berbagai pihak (stake holders) menjadi sangat penting.Wajah baru koperasi yang kekinian dan menarik bagi para generasi muda menjadi suatu keniscayaan agar koperasi mampu bertahan (sustain) dan mampu menjadi soko guru perekonomian.

\section{Keterbatasan dan Saran}

Keterbatasan dalam penelitian ini adalah jumlah sampel yang relatif kecil. Diharapkan penelitian lanjutan dapat menggunakan sampel dalam jumlah besar dan dengan metode yang berbeda, serta dapat menggunakan variabel - variabel lainnya yang berhubungan dengan motivasi, kepribadian, konsep diri dan perilaku individu lainnya.

\section{Implikasi}

Penelitian ini dapat memberikan masukan kepada koperasi CU Betang Asi Kalimantan Tengah untuk dapat mempertahankan eksistensinya di era saat ini agar dapat segera berinovasi mengikuti perkembangan zaman dengan mengutamakan pelayanan berbasis digital. Selain itu, untuk menarik minat generasi muda khususnya generasi $\mathrm{Z}$ dalam berkoperasi dibutuhkan effort yang lebih besar untuk menumbuhkan kembali ingatan dan kepercayaan masyarakat terhadap koperasi beserta manfaatnya.

\section{DAFTAR PUSTAKA}

CU Betang Asi. (2019, April). Retrieved Agustus 02, 2019, from CU Betang Asi: www.cubetangasi.com

Arifin, Y., Aminuyati, \& Syahrudin, H. (2015). Analisis Sikap Anggota dengan Keberadaan Unit Simpan Pinjan Koperasi Karyawan Sari Kusuma Desa Kuala Dua. Jurnal Pendidikan dan Pembelajaran, Vol. 4, No. 11, pp. 114.

Badan Pusat Statistik. (2012). Perkembangan Beberapa Indikator Utama SosialEkonomi Indonesia. Jakarta: Badan Pusat Statistik. 
Carollina, M., \& Sutarta, A. (2014). Peranan Credit Union Sebagai Lembaga Pembiayaan Mikro. Studi Kasus: Pada Usaha UMKM di Desa Tumbang Manggo, Kecamatan Sanaman Mantikei, Kabupaten Katingan, Provinsi Kalimantan Tengah, Tahun 2013. Modus, Vol. 26, No. 2, pp. 157-172.

Cooper, D. R., \& Schindler, P. S. (2014). Business Research Methods, 12th Edition. New York: McGraw-Hill.

CU Betang Asi. (2013, Maret 31). Kilas Balik Sejarah Berdirinya CU Betang Asi: Kopdit CU Betang Asi. Retrieved Agustus 02, 2019, from Kopdit CU Betang Asi: http://www.cubetangasi.com/2013/04/kilas-balik-sejarahberdirinya-cu.html

Dwidienawati, D., \& Gandasari, D. (2018). Undarstanding Indonesia's Generation Z. International Journal of Engineering \& Technology, 245-252.

Francis, T., \& Hoefel, F. (2018, November). Our Insights: McKinsey \& Company. Retrieved Agustus 02, 2019, from McKinsey \& Company: Consumer Packaged Goods: https://www.mckinsey.com/industries/consumerpackaged-goods/our-insights/true-gen-generation-z-and-its-implicationsfor-companies

Fromm, J. (2018, Maret). The Birth Years of Millennials and Generation Z: Millenial Marketing. Retrieved Agustus 01, 2019, from Millenial Marketing: http://www.millennialmarketing.com/2018/03/the-birth-yearsof-millennials-and-generation-z/

Hartono, J. (2003). Teori Portofolio dan Analisis Investasi. Yogyakarta: Badan Penerbit Fakultas Ekonomi (BPFE).

Irianto, S. (2017). Modul Pendidikan dan Pelatihan Tata Kelola Credit Union. Puskopdit BKCU Kalimantan.

Iswanto, I. (2019, Maret 27). Informasi Publik. (Pemerintah Kabupaten Gunung Mas) Retrieved $02 \quad$ Agustus, 2019, from https://gunungmaskab.go.id/index.php/2019/03/27/cu-betang-asi-telahmengumpulkan-aset-rp-200-miliar-lebih-tahun-2019/

Kementerian Koperasi. (2014, Desember 24). Awal Sejarah Koperasi: Kementerian Koperasi. Retrieved Agustus 03, 2019, from Kementerian Koperasi: $\quad$ http://kementeriankoperasi.com/awal-sejarah-koperasi-diindonesia/

Kementerian Koperasi. (2015, November 17). Asal Sejarah Terbentuknya Hari Koperasi Indonesia: Kementerian Koperasi. Retrieved Agustus 03, 2019, from Kementerian Koperasi: http://kementeriankoperasi.com/harikoperasi-indonesia/

Kenedy. (2019, Maret). 2019 CU Betang Asi Kumpulkan Aset Rp200 Miliar: Kabar Kalteng. Retrieved Agustus 02, 2019, from Kabar Kalteng: 
http://www.kabarkalteng.com/2019/03/2019-cu-betang-asi-kumpulkanaset-rp200.html

Lingu, A. L. (2017). The Influential Factos Towards Credit Union Members (Studies in CU Network Boards of CU in Kalimantan). Economics, Business and Accountancy Ventura, Vol. 14 , No. 01, pp. 54-70.

Robbins, S. P. (2005). Organizational Behavior. Toronto: Prentice Hall Inc.

Schermerhorn, J. R., Hunt, J. G., \& Osborn, R. N. (2005). Organizational Behavior. New York: John Wiley \& Sons.

Walgito, B. (2004). Pengantar Psikologi Umum. Yogyakarta: ANDI. 